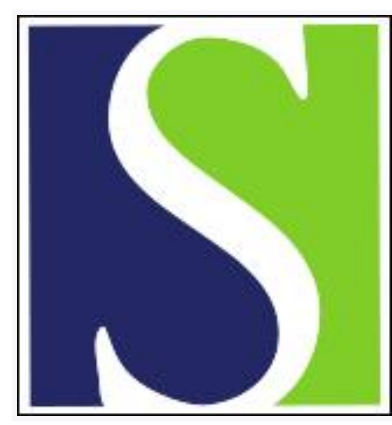

Scand J Work Environ Health 1976;2(1):19-31

https://doi.org/10.5271/sjweh.2838

Issue date: 1976

\title{
Dust exposure in Finnish foundries.
}

by Siltanen E, Koponen M, Kokko A, Engström B, Reponen J

The following article refers to this text: 1979;5(3):178-187

Key terms: dust exposure; dust measurement; Finland; foundry; foundry work

This article in PubMed: www.ncbi.nlm.nih.gov/pubmed/184524

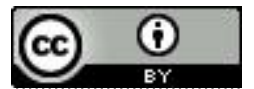




\title{
Dust exposure in Finnish foundries
}

\author{
by EERO SILTANEN, M.Sc., ${ }^{1}$ MATTI KOPONEN, M.Sc., ${ }^{2}$ ANTERO \\ KOKKO, M.Sc. (Eng.), ${ }^{3}$ BERNDT ENGSTRÖM, M.Sc., ${ }^{3}$ and JUHANI \\ REPONEN, B.Sc. ${ }^{4}$
}

\begin{abstract}
SILTANEN, E., KOPONEN, M., KOKKO, A., ENGSTRÖM, B. and REPONEN, J. Dust exposure in Finnish foundries. Scand. j. work environ. \& health 2 (1976) suppl. 1, 19-31. Dust measurements were made in 51 iron, 9 steel, and 8 nonferrous foundries, at which 4,316 foundrymen were working. The sampling lasted at least two entire shifts or work days continuously during various operations in each foundry. The dust samples were collected at fixed sites or in the breathing zones of the workers. The mass concentration was determined by weighing and the respirable dust fraction was separated by liquid sedimentation. The free silica content was determined by X-ray diffraction. In the study a total of 3,188 samples were collected in the foundries and 6,505 determinations were made in the laboratory. The results indicated a definite difference in the dust exposure during various operations. The highest dust exposures were found during furnace, cupola, and pouring ladle repair. During cleaning work, sand mixing, and shake-out operations excessive silica dust concentrations were also measured. The lowest dust concentrations were measured during melting and pouring operations. Moderate dust concentrations were measured during coremaking and molding operations. The results obtained during the same operations of iron and steel foundries were similar. The distribution of the workers into various exposure categories, the content of respirable dust and quartz, the correlation between respirable dust and total dust, and the correlation between respirable silica and total dust concentrations are discussed. Observations concerning dust suppression and control methods are briefly considered.
\end{abstract}

Key words: foundry work, dust exposure, dust measurement.

Nearly all technological foundry processes generate or release dust containing free crystalline silica, which, when inhaled in excess quantities, may cause silicosis. Reports concerning the dust situation in

1 Institute of Occupational Health, Helsinki, Finland. Present address: Technical Research Center of Finland, Work Safety Laboratory, Tampere, Finland.

2 Institute of Occupational Health, Helsinki, Finland. Present address: Outokumpu Oy, Helsinki, Finland.

3 Department of Industrial Hygiene and Toxicology, Institute of Occupational Health, Helsinki, Finland.

4 Institute of Occupational Health, Helsinki, Finland. Present address: Oy W. Rosenlew A.b, Pori, Finland.

Reprint requests to: Prof. Eero Siltanen, Work Safety Laboratory, Technical Research Center of Finland, Tammelanpuistokatu 13, FIN-33500 Tampere 50, Finland. foundries indicate that, in spite of efforts toward dust control, respirable silica dust still remains an outstanding health hazard in the foundry industry in many countries $(2,5,6,7,8,12,14,19,22)$. The different parameters of the dust measured and the variety of instruments and techniques employed usually prevent valid international comparisons of dust levels in foundries.

So far data on the dust situation in Finnish foundries have been insufficient. However, results of dust measurements from a limited group of foundries have been reported previously (16). Results of the study indicated that in many operations the workers in these factonies were exposed to high silica dust concen'trations.

The present paper reports a comprehensive systematic dust survey which was 
made during 1972-1974 in most Finnish iron and steel foundries operating at the time. Dust measurements were also made in a selected group of nonferrous alloy foundries in which molding sand was used.

In our study we particularly emphasized the evaluation of dust exposure in various work operations and in different occupations in foundries. Dust evaluations included the determination of the total mass concentration, the respirable fraction of dust, and the composition of the dust. Observations were also made of pertinent factors such as dust suppression and control methods, ventilation, and work methods. The results and detailed discussions concerning the methods have been partly reported elsewhere $(10,20)$.

\section{MATERIALS AND METHODS}

The foundries studied were divided into the following three groups according to the main production of castings: iron foundries, steel foundries, and nonferrous alloy foundries (light-alloys, brass and bronze). A dust survey was completed at 51 iron foundries, 9 steel foundries, and 8 nonferrous foundries. The number of foundry workers in the iron and steel foundries was 4,038 , and the nonferrous foundries employed 278 persons.

The gravimetric dust samples were taken either with personal samplers worn by workmen or with stationary samplers at fixed sites. The samples were collected mainly with single-stage sampling on membrane filters (with a nominal pore size of $0.8 \mu \mathrm{m}$ ). About half of the samples were collected in the breathing zone of workmen with the battery-operated personal samplers. Samples in the fixed positions were collected either on membrane filters with the aid of an electromagnetic piston pump or on a polystyrene filter by a high-volume sampler. The sampling devices used and air flow rates are presented in table 1.

The total mass concentration of the dust was determined by weighing the filter before and after sampling and using a semimicro balance with a sensitivity of $0.01 \mathrm{mg}$. The respirable fraction of the dust was separated afterwards in ethyl alcohol by means of a liquid sedimentation method (13). This method was selected because the permissible threshold limit value (TLV) for respirable quartz in Finland $\left(0.2 \mathrm{mg} / \mathrm{m}^{3}\right)(18)$ is the same as in Sweden, and it is based on the same separation method. According to the separation characteristics of the liquid sedimentation method particles with a $5-\mu \mathrm{m}$ diameter and a specific gravity of 2.6 $\mathrm{g} / \mathrm{cm}^{3}$ are collected quantitatively $(100 \%)$ and all coarse particles (larger than $5 \mu \mathrm{m}$ ) are separated efficiently. When respirable dust content and free-silica concentrations obtained by this method are compared with those obtained with sampling instruments meeting the requirements of the British Medical Research Council and the Johannesburg Pneumoconiosis Conference for size-selective sampling efficiency (11), the results should be reduced by the conversion factor 0.49 , as shown by Coenen (4). In the tables of the present article the conversion has not been made because in Finland the TLV for free crystalline silica is based, as already mentioned, upon the liquid sedimentation method. The Finnish TLV for the total mass concentration of inert or nuisance dust is $10 \mathrm{mg} / \mathrm{m}^{3}$ (18).

At the beginning of the study we also used aerodynamic size-selective personal samplers, which separate the coarse dust fraction during sampling with a small cyclone and collect the respirable fraction on a filter. The samples collected in this way were not large enough however for a free-silica analysis, and we therefore discontinued their use.

The free-silica content (quartz, cristobalite and tridymite) of the respirable fraction of dust was determined by the $\mathrm{X}$-ray differaction method $(3,13)$.

In this study a total of 3,188 samples were collected in the foundries. Table 2 shows the distribution of the samples with respect to method of collection, type of sample, and number of analyses.

The sampling cycle in each foundry lasted at least two entire shifts or work days continuously for the various types of work. The sampling always started shortly after the beginning of a shift, usually at 0700 . The total mass concentrations were measured continuously during foundry operating periods by successive, 2- to 4 -h 
samples at fixed locations and 4- to 8-h samples in the breathing zone of the workers. The sampling program, including the choice of the sampling locations in each foundry, followed the same pattern if possible, so that measurements from all the most important work operations would be included and the results would be as comparable as possible.

\section{RESULTS}

\section{Average dust and respirable silica concentrations}

The results were divided into groups according to the type of foundry, work operations, and methods. In table 3 the results of the iron foundry measurements

Table 1. Sampling devices and analyzing methods used in the study.

\begin{tabular}{llll}
\hline $\begin{array}{l}\text { Sampling pumps and } \\
\text { accessories }\end{array}$ & $\begin{array}{l}\text { Filter holders and } \\
\text { filters }\end{array}$ & $\begin{array}{l}\text { Air flow } \\
\text { rate } \\
(1 / \mathrm{min})\end{array}$ & $\begin{array}{l}\text { Separation of respirable of free crys- } \\
\text { fraction }\end{array}$
\end{tabular}

\section{A. STATIONARY DEVICES}

Electromagnetic piston pump Reciprotor $406 \mathrm{G}$ (Reciprotor Co., Copenhagen) with a dry gas meter (Nordgas U2 $1 / 2 \mathrm{~T}$ ) and a miniature variable transformer $0.7 \mathrm{~A}$ (Philips, Holland)

MSA Fixt-Flo highvolume sampler (MSA, Pittsburgh) with a conical hood (self-made)
Millipore Field

Monitor MAWG and Millipore Filter AAWPO37, pore size $0.8 \mu \mathrm{m}$ (Millipore Corp., U.S.A.)

$16-20$

Polystyrene filter Microsorban $99 / 97$, diam. $160 \mathrm{~mm}$ (Delbag-Luftfilter, Berlin)

\section{B. PORTABLE} DEVICES

MSA Monitaire Sampler, model G (MSA, Pittsburgh) with a pulsation damper Casella B 7634 (Casella \& Co., London)

MSA Monitaire Sampler model $G$ with a twostage sampler Casella A 7650/1 (Casella \& Co., London)
Millipore

Field Monitor and Millipore Filter AAWPO37, pore size $0.8 \mu \mathrm{m}$ (Millipore Corp., U.S.A.

Membrane filter, pore size $5 \mu \mathrm{m}$, in holder integral with a cyclone
Modified Andreasen liquid sedimentation in ethyl alcohol

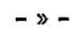

From the respirable fraction by $\mathrm{X}$-ray diffraction

meeting the
BMRCa
criterion (1)

a British Medical Research Council.

Table 2. Samples collected and analyzed during the study.

\begin{tabular}{|c|c|c|c|c|c|c|}
\hline \multirow{2}{*}{$\begin{array}{l}\text { Type of } \\
\text { foundry }\end{array}$} & \multicolumn{2}{|c|}{ Collected samples } & \multicolumn{3}{|c|}{ Analyzed samples } & \multirow[b]{2}{*}{ Total } \\
\hline & $\begin{array}{l}\text { Stationary } \\
\text { devices }\end{array}$ & $\begin{array}{c}\text { Portable } \\
\text { devices }\end{array}$ & $\begin{array}{l}\text { Respirable } \\
\text { fraction }\end{array}$ & Quartz & $\begin{array}{l}\text { Cristobalite } \\
\text { or tridymite }\end{array}$ & \\
\hline Iron & 1,073 & 1,140 & 1,230 & 1,201 & 20 & 4,664 \\
\hline Steel & 342 & 392 & 380 & 378 & 50 & 1,542 \\
\hline Nonferrous & 121 & 120 & 29 & 29 & - & 299 \\
\hline Total & 1,536 & 1,652 & 1,639 & 1,608 & 70 & 6,505 \\
\hline
\end{tabular}


Table 3. Means and medians of the measured dust concentrations $\left(\mathrm{mg} / \mathrm{m}^{3}\right)$ from the iron foundries and the number of workmen in various operations.

\begin{tabular}{|c|c|c|c|c|c|}
\hline \multirow{2}{*}{ Operation } & \multicolumn{2}{|c|}{ Total dust } & \multicolumn{2}{|c|}{$\begin{array}{l}\text { Silica in respirable } \\
\text { fraction }(<5 \mu \mathrm{m})\end{array}$} & \multirow{2}{*}{$\begin{array}{l}\text { Number of } \\
\text { workers }\end{array}$} \\
\hline & Mean & Median & Mean & Median & \\
\hline Sand preparation & 21 & 12 & 0.78 & 0.37 & 106 \\
\hline Molding & 8.6 & 6.9 & 0.31 & 0.22 & 486 \\
\hline Coremaking & 5.2 & 4.5 & 0.24 & 0.20 & 234 \\
\hline Melting & 8.4 & 6.2 & 0.35 & 0.14 & 147 \\
\hline Furnace repair & 34 & 16 & 2.25 & 1.13 & 54 \\
\hline Pouring & 8.5 & 7.8 & 0.19 & 0.18 & 146 \\
\hline Shake-out & 19 & 11 & 0.53 & 0.38 & 153 \\
\hline Cleaning & 18 & 11 & 0.74 & 0.52 & 418 \\
\hline Other & 9.7 & 4.4 & 0.41 & 0.19 & 497 \\
\hline Total & & & & & 2,241 \\
\hline
\end{tabular}

Table 4. Means and medians of the measured dust concentrations $\left(\mathrm{mg} / \mathrm{m}^{3}\right)$ from the steel foundries and the number of workmen in various operations.

\begin{tabular}{|c|c|c|c|c|c|}
\hline \multirow{2}{*}{ Operation } & \multicolumn{2}{|c|}{ Total dust } & \multicolumn{2}{|c|}{$\begin{array}{l}\text { Silica in respirable } \\
\text { fraction }(<5 \mu \mathrm{m})\end{array}$} & \multirow{2}{*}{$\begin{array}{l}\text { Number of } \\
\text { workers }\end{array}$} \\
\hline & Mean & Median & Mean & Median & \\
\hline Sand preparation & 13 & 9.7 & 0.55 & 0.34 & 46 \\
\hline Molding & 5.8 & 4.2 & 0.27 & 0.21 & 249 \\
\hline Coremaking & 4.6 & 3.5 & 0.24 & 0.17 & 121 \\
\hline Melting & 5.0 & 4.1 & 0.19 & 0.14 & 89 \\
\hline Furnace and ladle repair & 27 & 5.6 & 5.26 & 2.10 & 33 \\
\hline Pouring & 8.2 & 4.3 & 0.24 & 0.11 & 48 \\
\hline Shake-out & 8.6 & 5.9 & 0.42 & 0.27 & 66 \\
\hline Cleaning & 21 & 17 & 0.45 & 0.27 & 404 \\
\hline Other & 9.7 & 4.4 & 0.41 & 0.19 & 497 \\
\hline Total & & & & & 1,553 \\
\hline
\end{tabular}

are presented according to the work operations. The results show a considerable difference in dust exposure during various operations. The hazard caused by silica dust was the most severe during the furnace and cupola repairs and during the repairing of pouring ladles. During cleaning work, sand mixing, and shake-out operations, concentrations considerably exceeding the current TLV of respirable silica were measured. The lowest dust concentrations were measured during melting and pouring, the median values being 0.14 and $0.18 \mathrm{mg} / \mathrm{m}^{3}$ for respirable quartz, respectively. During sand preparation, furnace repair work, shake-out operations, and fettling work in cleaning shops, total dust concentrations even exceeded the TLV for inert dust. In a couple of foundries some of the samples collected during various operations contained exceptionally high dust concentrations which greatly raised the arithmetic mean values of the dust concentrations. In the evaluation of the average dust hazard in Finnish foundries, the use of calculated median dust values is thus more satisfactory than the use of arithmetic mean values because the effect of exceptionally high single concentrations of dust are eliminated.

In table 4 results obtained from dust measurements in steel foundries are presented. The results again indicate definite differences in the total dust and respirable silica concentrations of the various work phases although the concentration ranges were distributed more evenly than in the iron foundries. The highest dust concentrations were measured during furnace work, sand mixing, shake-out operations, and fettling work (cleaning). 
A comparison of the results obtained in the same operations of iron and steel foundries show that the measured respirable free-silica concentrations were similar in both groups, especially if the median values are considered.

The results obtained in nonferrous foundries included in the study are shown in table 5. The results indicate that the average conditions in the fettling (cleaning) shops of nonferrous foundries are more severe than in other operations.
Distribution of respirable silica concentrations

Table 6 shows the percentage distribution of respirable free-silica concentrations during various operations in iron foundries. Sand preparation, shake-out, and casting cleaning were the dustiest operations. The dust situation was best in coremaking and pouring operations, but collected samples from these operations also contained excessive concentrations of fine quartz dust, 42 and $35 \%$, respectively.

Table 5. Means and medians of the measured dust concentrations $\left(\mathrm{mg} / \mathrm{m}^{3}\right)$ from the nonferrous foundries and the number of workers in various operations.

\begin{tabular}{|c|c|c|c|c|c|c|c|}
\hline \multirow{2}{*}{ Operation } & \multicolumn{3}{|c|}{ Total dust } & \multicolumn{3}{|c|}{$\begin{array}{l}\text { Silica in respirable } \\
\text { fraction }(<5 \mu \mathrm{m})\end{array}$} & \multirow{2}{*}{$\begin{array}{l}\text { Number of } \\
\text { workers }\end{array}$} \\
\hline & $\begin{array}{l}\text { Number of } \\
\text { samples }\end{array}$ & Mean & Median & $\begin{array}{l}\text { Number of } \\
\text { samples }\end{array}$ & Mean & Median & \\
\hline Molding & 66 & 6.3 & 5.6 & 15 & 0.22 & 0.17 & 89 \\
\hline Melting & 60 & 5.0 & 4.4 & - & - & - & 56 \\
\hline \multicolumn{8}{|l|}{ Pouring and } \\
\hline shake-out & 72 & 5.8 & 2.8 & 8 & 0.42 & 0.30 & 31 \\
\hline Cleaning & 43 & 7.9 & 5.3 & 8 & 0.49 & 0.50 & 117 \\
\hline Total & 241 & & & 31 & & & 293 \\
\hline
\end{tabular}

Table 6. Percentage distribution of free-silica concentrations $\left(\mathrm{mg} / \mathrm{m}^{3}\right)$ in the respirable fraction of dust during various operations in the iron foundries.

\begin{tabular}{lccccccc}
\hline & & \multicolumn{5}{c}{ Range of free silica concentration } \\
\cline { 3 - 8 } Operation & $\begin{array}{c}\text { Number of } \\
\text { samples }\end{array}$ & $<0.06$ & $0.06-$ & $0.12-$ & $0.24-$ & $0.48-$ & $>0.95$ \\
& & & 0.11 & 0.23 & 0.47 & 0.96 & \\
\hline Sand preparation & 134 & 1 & 6 & 27 & 31 & 20 & 15 \\
Molding & 393 & 6 & 17 & 28 & 34 & 11 & 4 \\
Coremaking & 106 & 8 & 11 & 39 & 33 & 8 & 1 \\
Pouring & 102 & 4 & 31 & 30 & 25 & 9 & 1 \\
Shake-out & 156 & 3 & 15 & 15 & 26 & 20 & 21 \\
Cleaning & 227 & 1 & 10 & 15 & 28 & 18 & 28 \\
Other & 42 & - & 7 & 26 & 31 & 17 & 19 \\
\hline
\end{tabular}

Table 7. Percentage distribution of free-silica concentrations $\left(\mathrm{mg} / \mathrm{m}^{3}\right)$ in the respirable fraction of dust measured during various operations in the steel foundries.

\begin{tabular}{|c|c|c|c|c|c|c|c|}
\hline \multirow[b]{2}{*}{ Operation } & \multirow{2}{*}{$\begin{array}{l}\text { Number of } \\
\text { samples }\end{array}$} & \multicolumn{6}{|c|}{ Range of free silica concentration } \\
\hline & & $<0.06$ & $\begin{array}{l}0.06- \\
0.11\end{array}$ & $\begin{array}{l}0.12- \\
0.23\end{array}$ & $\begin{array}{l}0.24- \\
0.47\end{array}$ & $\begin{array}{l}0.48- \\
0.96\end{array}$ & $>0.96$ \\
\hline Sand preparation & 63 & 2 & 13 & 25 & 22 & 24 & 14 \\
\hline Molding & 85 & 7 & 17 & 35 & 27 & 11 & 3 \\
\hline Coremaking & 34 & - & 23 & 47 & 21 & 6 & 3 \\
\hline Repairing furnaces & & & & & & & \\
\hline and ladles & 12 & - & - & 8 & 8 & 25 & 59 \\
\hline Pouring & 9 & 一 & 56 & 11 & 22 & - & 11 \\
\hline Shake-out & 56 & 4 & 23 & 11 & 30 & 25 & 7 \\
\hline Cleaning & 76 & 4 & 9 & 30 & 34 & 12 & 11 \\
\hline Other & 36 & - & 19 & 45 & 27 & 3 & 6 \\
\hline
\end{tabular}


The distribution of free-silica concentrations in steel foundries can be found in table 7. The dust situation was worst during furnace, cupola, and pouring ladle repairing; $92 \%$ of the samples collected from these operations contained high concentrations of respirable free silica. Otherwise the dust concentrations in steel foundries were nearly the same as in iron foundries in respect to distribution ranges.

\section{Distribution of workers into exposure categories}

In this study the dust measurements were based on full-shift sampling of the environment of workmen engaged in various foundry operations, and the different activities involved in each operation were taken into account. Because the number of samples collected in various operations corresponded approximately to the distribution of workmen in each operation in respect to the overall operation, it was possible to classify the foundrymen into various exposure categories. The distribu- tion of the iron foundry workers in various exposure categories is shown in table 8 . In sand mixing $66 \%$ of the workmen were exposed to excessive silica dust concentrations. About $67 \%$ of the employees engaged in shake-out operations and $74 \%$ of the workmen cleaning castings were also exposed to high concentrations of silica.

The comparable distribution of steel foundry workers is shown in table 9. The most harmful operations with respect to silica dust were shake-out, casting cleaning, and sand preparation, in which about $60 \%$ of the workmen were exposed to high silica concentrations. In the repair of furnaces and pouring ladles nearly all workmen were exposed to excessive concentrations. However, this group of workers was very small. In general the silioa dust situation in steel foundries seemed to be slightly better than in iron foundries.

\section{Comparison of data from breathing-} zone and fixed-site samples

Fig. 1 shows the total mass concentrations of dust in various operations in iron

Table 8. Percentage distribution of iron foundry workmen according to category of silica dust exposure.

\begin{tabular}{|c|c|c|c|c|}
\hline \multirow{2}{*}{ Operation } & \multicolumn{3}{|c|}{ Respirable free-silica concentration } & \multirow{2}{*}{$\begin{array}{c}\text { Total } \\
\text { number of } \\
\text { workmen }\end{array}$} \\
\hline & $<0.12 \mathrm{mg} / \mathrm{m}^{3}$ & $0.12-0.24 \mathrm{mg} / \mathrm{m}^{3}$ & $>0.24 \mathrm{mg} / \mathrm{m}^{3}$ & \\
\hline Sand preparation & 7 & 27 & 66 & 106 \\
\hline Molding & 23 & 28 & 49 & 486 \\
\hline Coremaking & 19 & 39 & 42 & 234 \\
\hline Pouring & 35 & 30 & 35 & 146 \\
\hline Shake-out & 18 & 15 & 67 & 153 \\
\hline Cleaning & 11 & 15 & 74 & 418 \\
\hline Other & 7 & 26 & 67 & 741 \\
\hline
\end{tabular}

Table 9. Percentage distribution of steel foundry workmen according to category of silica dust exposure.

\begin{tabular}{|c|c|c|c|c|}
\hline \multirow{2}{*}{ Operation } & \multicolumn{3}{|c|}{ Respirable free-silica concentration } & \multirow{2}{*}{$\begin{array}{c}\text { Total } \\
\text { number of } \\
\text { workmen }\end{array}$} \\
\hline & $<0.12 \mathrm{mg} / \mathrm{m}^{3}$ & $0.12-0.24 \mathrm{mg} / \mathrm{m}^{3}$ & $>0.24 \mathrm{mg} / \mathrm{m}^{3}$ & \\
\hline Sand preparation & 15 & 25 & 60 & 46 \\
\hline Molding & 24 & 35 & 41 & 249 \\
\hline Coremaking & 23 & 47 & 30 & 121 \\
\hline Repairing furnaces and ladles & - & 8 & 92 & 33 \\
\hline Pouring & 56 & 11 & 33 & 48 \\
\hline Shake-out & 27 & 11 & 62 & 66 \\
\hline Cleaning & 13 & 30 & 57 & 404 \\
\hline Other & 19 & 45 & 36 & 497 \\
\hline
\end{tabular}




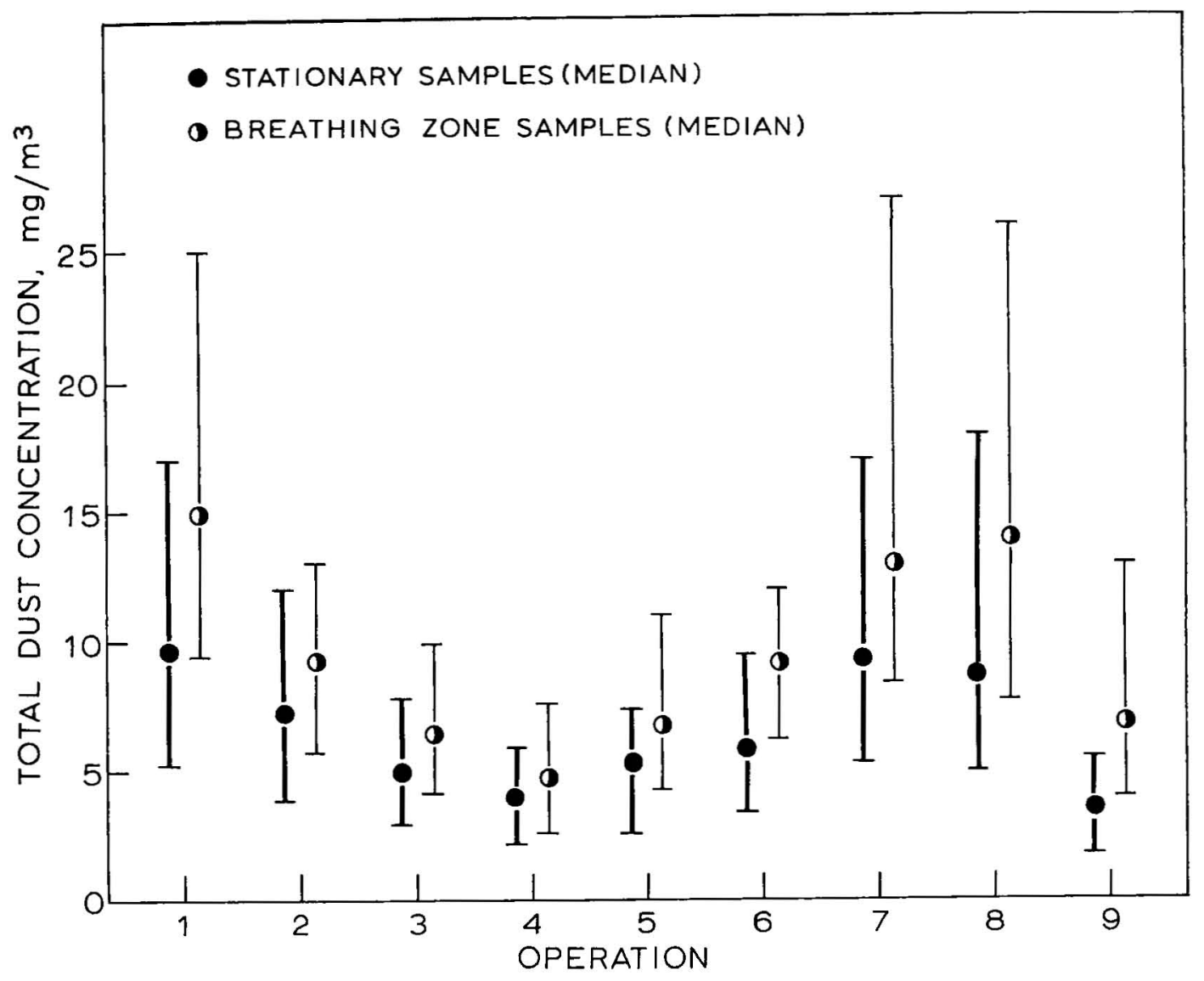

Fig. 1. Comparison of the medians and the 25 and 75 percentiles of the distributions of total dust collected by stationary and portable samplers in iron foundries. $(1=$ sand preparation, $2=$ hand molding, $3=$ machine and sandslinger molding, $4=$ coremaking, $5=$ melting, $6=$ pouring, $\quad 7=$ shake-out, $\quad 8=$ cleaning, $\quad$ and $9=$ other operations)

foundries. In the operations the dust concentrations obtained from the breathing zones were considerably higher than those from the fixed-site samples. During machine and sandslinger molding, handmolding, coremaking, melting, and pouring, the measured total dust concentrations from the breathing-zone samples were about $1-2 \mathrm{mg} / \mathrm{m}^{3}$ higher than concentrations from the stationary samples. During sand preparation, shake-out operations, and casting cleaning the corresponding difference was about $3-5 \mathrm{mg} / \mathrm{m}^{3}$.

\section{Content of respirable dust and quartz}

The average values for the respirable dust content in collected dust samples did not fluctuate much from one foundry opera- tion to another (table 10). The content of the respirable fraction ranged between 16 and $75 \%$ during molding, the average being $44.7 \%$. Fig. 2 shows the frequency distribution for samples collected during molding according to the respirable dust content. About $30-60 \%$ of most samples was fine respirable dust. The comparable distribution of the samples according to the range of respirable free-silica content is presented in fig. 3 . The figure indicates that, in more than half of the samples (about $66 \%$ collected during molding work, respirable free silica ranged from 3 to $9 \%$.

\section{Content of cristobalite and tridymite}

Cristobalite was detected in 41 samples. 
Table 10. Average content of respirable fraction and quartz measured in the foundry dust.

\begin{tabular}{|c|c|c|c|c|c|c|}
\hline \multirow{2}{*}{ Operation } & \multicolumn{3}{|c|}{ Respirable fraction } & \multicolumn{3}{|c|}{ Quartz content } \\
\hline & Average $(0 / 0)$ & Range & Samples & Average $(0 / 0)$ & Range & Samples \\
\hline Sand preparation & 42.5 & $15-74$ & 99 & 8.1 & $0-23$ & 100 \\
\hline Molding & 44.7 & $16-75$ & 315 & 8.4 & $0-30$ & 315 \\
\hline Coremaking & 49.1 & $18-78$ & 80 & 9.3 & $3-20$ & 80 \\
\hline Melting & 33.7 & $13-46$ & 6 & 8.8 & $5-17$ & 6 \\
\hline Furnace repair & 41.2 & $17-57$ & 26 & 10.7 & $3-22$ & 26 \\
\hline Pouring & 37.9 & $19-59$ & 80 & 7.3 & $0-20$ & 80 \\
\hline Shake-out & 34.5 & $11-64$ & 110 & 7.6 & $0-25$ & 110 \\
\hline Cleaning & 37.5 & $12-74$ & 178 & 13.0 & $3-44$ & 178 \\
\hline Other & 45.7 & $21-74$ & 48 & 10.6 & $4-21$ & 48 \\
\hline
\end{tabular}

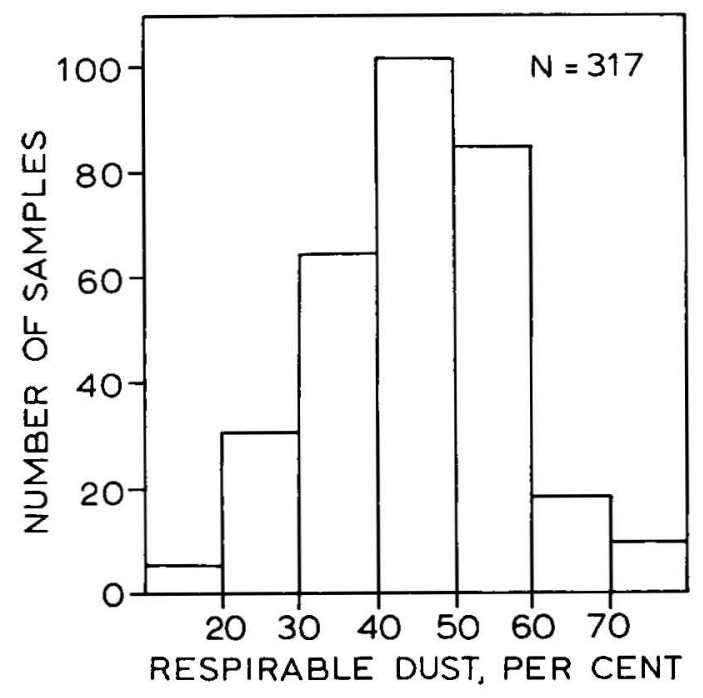

Fig. 2. Distribution of molding samples by range of respirable dust content.

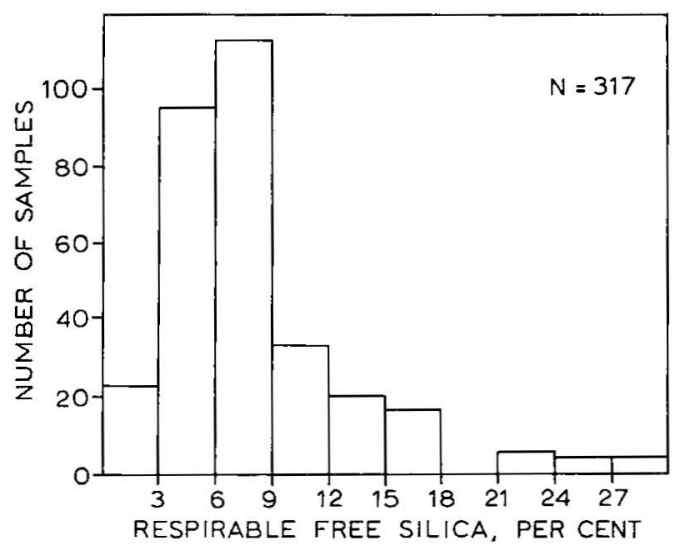

Fig. 3. Distribution of molding samples by range of free-silica content.
Only one of the examined samples also contained traces of tridymite. Cristobalite was found in eight iron foundry samples, all of which were collected during furnace and cupola maintenance or the repair of pouring ladles. The content of cristobalite ranged from 2 to $6 \%$ in the respirable dust. Cristobalite was present in 33 samples collected during various operations in steel foundries. Table 11 shows the distribution of steel foundry samples containing cristobalite. Traces of tridymite were detected in one sample taken during brick sawing.

Correlation between respirable dust fraction and total dust concentrations

The determinations of respirable dust fraction and total dust concentrations from samples taken from the same operations of iron and steel foundries were statistically analyzed and compared. The results are listed in table 12 . Inspection of the table indicates a good correlation between the respirable fraction and total dust concentrations in various operations. The calculated correlation coefficients varied from 0.8055 during shake-out operations to 0.9380 during molding work. The calculated regression equations and standard error of the estimates, which can be used as data to establish the lines of best fit and the confidence limits of these lines, are also shown in the table. Fig. 4 illustrates this relationship for the data from sand preparation. The results of the dust measurements are plotted and the line of best fit is shown by a solid line and the confidence limits at the $95 \%$ level are plotted by broken lines. The regression equations or the lines of 
best fit could be used for predicting the concentration of respirable fraction from predetermined total dust mass concentration in different foundry operations.

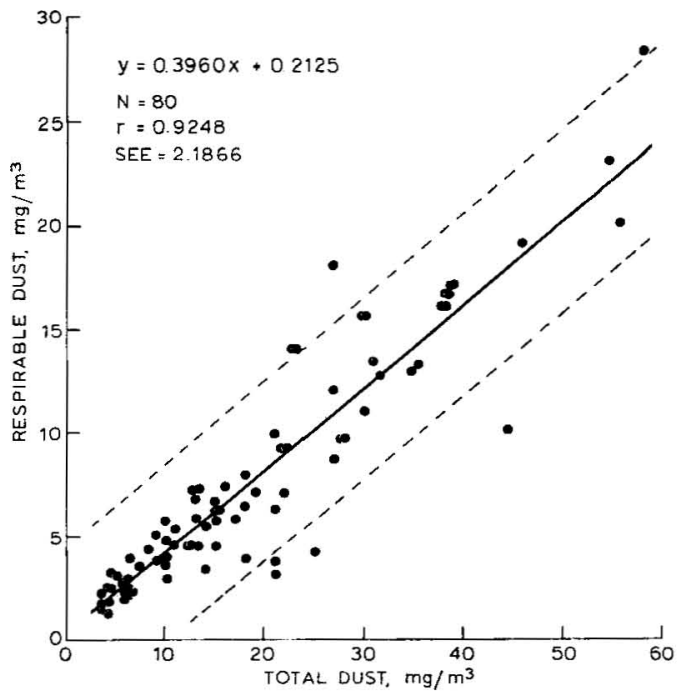

Fig. 4. Comparison of total dust (x) and respirable dust fraction (y) concentrations during sand preparation in iron and steel foundries. (SEE $=$ standard error of the estimate)

Table 11. Cristobalite content of the samples collected in the steel foundries.

\begin{tabular}{lcc}
\hline Operation & $\begin{array}{c}\text { Number of } \\
\text { samples }\end{array}$ & $\begin{array}{c}\text { Cristobalite } \\
\text { in respirable } \\
\text { fraction }\end{array}$ \\
\hline Sand preparation & 2 & 1 \\
Brick sawing & 3 & $1-2$ \\
Furnace maintenance & 7 & $1-16$ \\
Shake-out & 9 & 2 \\
Cleaning & 7 & $1-10$ \\
Melting & 4 & 2 \\
Crane operating & 1 & 2 \\
\hline
\end{tabular}

Correlation between respirable silica and total dust

The respirable free-silica determinations and the total dust concentrations from the same samples from the iron and steel foundries were also statistically analyzed and compared. Table 13 shows the results. The correlation between respirable silica and total dust concentration was not so good as between respirable dust fraction and total dust concentration. The correlation coefficients ranged from 0.4222 for coremaking to 0.7828 for cleaning work. It is likely that the correlation would have been far better if the different silica contents in the original type of molding sand used were taken into consideration and if the comparisons were made only between the results from foundry sand of the same type. Dust generated from various types of foundry sand contain very different amounts of crystalline silica, as is shown in table 14. Olivine sand was used in some steel foundries as a replacement for the conventional silica type of sand. However, there was still a possibility for silica to be present in the air because of the continued use of bentonite, silica type cores, and other silica compounds. Chromite sand was used in only one foundry.

\section{Comparison of the dust measurements with results from other countries}

Many different air sampling techniques and methods of measuring dust have been used in different countries. The variation in the measurement of the respirable fraction of dust because of the difference in devices has been discussed by many authors $(4,15,17,21)$. In general, when

Table 12. Relation between respirable dust (y) and total dust $(\mathrm{x})$ concentrations in the iron and steel foundries.

\begin{tabular}{lcccc}
\hline Operation & $\begin{array}{c}\text { Number of } \\
\text { samples }\end{array}$ & $\begin{array}{c}\text { Regression equation } \\
(\mathrm{y}=\mathrm{ax}+\mathrm{b})\end{array}$ & $\begin{array}{c}\text { Correlation } \\
\text { coefficient } \\
(\mathrm{r})\end{array}$ & $\begin{array}{c}\text { Standard } \\
\text { error of the } \\
\text { estimate }\end{array}$ \\
\hline Sand preparation & 80 & $\mathrm{y}=0.3960 \mathrm{x}+0.2125$ & 0.9248 & 2.1866 \\
Coremaking & 68 & $\mathrm{y}=0.3947 \mathrm{x}+0.4659$ & 0.8970 & 0.7673 \\
Molding & 216 & $\mathrm{y}=0.5124 \mathrm{x}-0.6532$ & 0.9380 & 2.8296 \\
Shake-out & 75 & $\mathrm{y}=0.3350 \mathrm{x}+0.8326$ & 0.8055 & 3.7402 \\
Cleaning & 105 & $\mathrm{y}=0.6258 \mathrm{x}+0.3384$ & 0.8938 & 1.9858 \\
\hline
\end{tabular}


Table 13. Relation between respirable silica dust $(\mathrm{y})$ and total dust $(\mathrm{x})$ concentrations in the iron and steel foundries.

\begin{tabular}{lcccc}
\hline Operation & $\begin{array}{c}\text { Number of } \\
\text { samples }\end{array}$ & $\begin{array}{c}\text { Regression equation } \\
(\mathrm{y}=\mathrm{ax}+\mathrm{b})\end{array}$ & $\begin{array}{c}\text { Correlation } \\
\text { coefficient } \\
(\mathrm{r})\end{array}$ & $\begin{array}{c}\text { Standard } \\
\text { error of the } \\
\text { estimate }\end{array}$ \\
\hline Sand preparation & 80 & $\mathrm{y}=0.0461 \mathrm{x}-0.0912$ & 0.6150 & 0.7925 \\
Coremaking & 68 & $\mathrm{y}=0.0313 \mathrm{x}+0.1068$ & 0.4222 & 0.2652 \\
Molding & 200 & $\mathrm{y}=0.0261 \mathrm{x}+0.052$ & 0.6718 & 0.2342 \\
Shake-out & 76 & $\mathrm{y}=0.0095 \mathrm{x}+0.0332$ & 0.6511 & 0.3788 \\
Cleaning & 180 & $\mathrm{y}=0.0333 \mathrm{x}+\mathbf{0 . 0 4 5 4}$ & 0.7828 & 0.5133 \\
\hline
\end{tabular}

Table 14. Average quartz content in respirable dust in foundries using different grades of sand.

\begin{tabular}{clc}
\hline Foundry & Type of sand $\begin{array}{c}\text { Average quartz content } \\
\text { in }\end{array}$ & $\begin{array}{c}\text { respirable dust } \\
(\%)\end{array}$ \\
\hline & & 1.5 \\
1 & Olivine sand & 2.7 \\
2 & Chromite sand & 7.8 \\
3 & Sea bottom sand & 5.8 \\
4 & Sea bottom sand & \\
5 & Crushed quartzite & 15.1 \\
\hline
\end{tabular}

different sampling equipment has been used, the most comparable results are those of the total mass concentrations of dust (17). Tables 15 and 16 show the mean and median concentrations obtained during this study and during a dust study in Swedish iron and steel foundries in 19681972 (6). The results ought to be reasonably comparable because similar sampling methods were used in both countries. The results obtained during various operations in Swedish and Finnish iron foundries are similar except for the furnace repair. Table 16 indicates that dust exposure is greater in Finnish steel foundries than in Swedish steel foundries.

\section{Observations concerning dust suppression and control}

Effective dust control in foundries depends to a great extent on a good initial design of machinery, installations, and operations. Most of the foundries studied still operated in old buildings, and no attention had been paid to dust control when they were designed. Successful dust control measures had been, however, implemented in some foundries.
Dust control and evaluation programs were in effect in only some large foundries. Continuous dust monitoring was not routine in any foundry, and only sporadic dust measurements had usually been made.

\section{DISCUSSION}

The total mass and respirable free-silica concentrations measured during different operations varied considerably, but during the same operations in iron and steel foundries results were similar.

Furnace repair work, fettling in cleaning shops, sand preparation, and shake-out operations had the highest dust exposure of all foundry operations studied, and melting and pouring operations had the lowest dust exposure. The results were similar to the observations made in a previous study (16).

The results of the study indicate that the majority of foundry workers is exposed to high, above $0.24 \mathrm{mg} / \mathrm{m}^{3}$, respirable silica dust concentrations in all foundry operations with the exception of molding, coremaking, and pouring, and therefore a definite silicosis hazard exists in many of the Finnish foundries. When data from silicosis studies are compared with those of dust studies, it must be kept in mind that, except in cases of massive exposure to high silica bearing dust, a number of years are required, sometimes 20 or more, before the evidence of disease appears in chest radiographs. The low prevalence of silicosis observed in the medical part of our project, reported elsewhere (9), can be explained partly by the relatively short operating time of many of the Finnish foundries and partly by the high turnover of the workers especially in the most dusty operations. Many Finnish foundries were 
established only after the Second World War and therefore have been in operation only 25 to 30 years.

The content of the respirable dust fraction did not vary considerably in different operations. The average content of respirable dust ranged from 33 to $49 \%$. The variation in the free-silica content of respirable dust ranged from 7 to $13 \%$. Cristobalite was found more often in the samples collected during the repair of furnaces and pouring ladles.

A high linear correlation was found between the respirable fraction and total mass concentration of dust collected during various operations, but the linear correlation between the total mass and respirable silica concentrations was lower.

The use of olivine or chromite sand as a replacement for a silica type of sand reduces the silica content of dust, and thus the silicosis hazard, although the degree of reduction was not studied satisfactorily in this investigation. Crushed quartzite sand used as molding sand seems more dangerous than any other type of sand in regard to the silicosis hazard.
Well-organized dust control and evaluation programs are rarely found in Finnish foundries. The complete elimination of dust is not possible in foundries, but with the best technology available, it would often be possible to keep the dust at an acceptable level. The conditions can be prevented only through a combination of methods, which include dust suppression at the source, good maintenance, proper handling of material, planned waste disposal, enclosure of foundry equipment, installation of local exhaust systems, and good general ventilation to capture and remove the dust that is generated. Regular dust monitoring is essential, and the use of effective personal protective devices is needed if the hazard cannot be elliminated in any other manner.

General recommendations concerning dust suppression and control and regular dust sampling and evaluation were given to each foundry. The ideal method for measuring the silica dust hazard would seem to be a sampling of respirable dust fraction with a two-stage sampler within the breathing zone of individuals and an

Table 15. Comparison of the means and medians of total dust concentrations $\left(\mathrm{mg} / \mathrm{m}^{3}\right)$ in $\mathrm{Swe}-$ dish and Finnish iron foundries.

\begin{tabular}{|c|c|c|c|c|c|c|c|c|}
\hline \multirow{3}{*}{ Operation } & \multicolumn{4}{|c|}{ Fixed-site samples } & \multicolumn{4}{|c|}{ Breathing-zone samples } \\
\hline & \multicolumn{2}{|c|}{ Sweden $1968-1969$} & \multicolumn{2}{|c|}{ Finland $1972-1974$} & \multicolumn{2}{|c|}{ Sweden $1968-1969$} & \multicolumn{2}{|c|}{ Finland $1972-1974$} \\
\hline & Mean & Median & Mean & Median & Mean & Median & Mean & Median \\
\hline Sand preparation & 16.3 & 9.5 & 18.6 & 9.7 & 16.2 & 12.3 & 21.6 & 14.5 \\
\hline Coremaking & 4.4 & 3.8 & 4.6 & 4.0 & 6.2 & 6.6 & 5.9 & 4.8 \\
\hline Molding & 7.8 & 6.9 & 7.0 & 6.1 & 8.4 & 7.8 & 9.2 & 6.4 \\
\hline Shake-out & 15.4 & 10.8 & 15.6 & 9.4 & 16.3 & 13.7 & 22.5 & 12.9 \\
\hline Cleaning & 12.7 & 8.8 & 14.1 & 8.7 & 17.2 & 13.9 & 21.6 & 14.0 \\
\hline Furnace repair & 128.0 & 15.0 & 8.3 & 5.9 & 68.3 & 18.2 & 37.0 & 17.0 \\
\hline
\end{tabular}

Table 16. Comparison of the means and medians of total dust concentrations $\left(\mathrm{mg} / \mathrm{m}^{3}\right)$ in Swedish and Finnish iron foundries.

\begin{tabular}{|c|c|c|c|c|c|c|c|c|}
\hline \multirow{3}{*}{ Operation } & \multicolumn{4}{|c|}{ Fixed-site samples } & \multicolumn{4}{|c|}{ Breathing-zone samples } \\
\hline & Sweden & $1968-1971$ & Finland & $1972-1974$ & Sweden & $1968-1971$ & Finland & $1972-1974$ \\
\hline & Mean & Median & Mean & Median & Mean & Median & Mean & Median \\
\hline Sand preparation & 3.8 & 3.5 & 11.7 & 6.8 & 6.4 & 4.4 & 13.6 & 12.0 \\
\hline Molding & 2.4 & 2.6 & 4.3 & 3.5 & 4.2 & 4.1 & 7.2 & 4.8 \\
\hline Shake-out & & & 5.3 & 4.2 & 7.6 & 7.0 & 12.6 & 10.0 \\
\hline Cleaning & 7.8 & 5.6 & 15.6 & 13.0 & 10.6 & 8.7 & 25.8 & 22.0 \\
\hline
\end{tabular}


analysis for the free silica in each personal sample. However, with the present sampling devices and analyzing techniques this type of sampling is difficult and impractical. Therefore it was recommended that foundries use stationary sampling on membrane filters and determine the mass concentration of dust by weighing the filter before and after sampling a known volume of air. To simplify the assessment of dust hazard, we recommended the following "threshold limit values" for the total mass concentration of foundry dust in various operations: sand preparation $5.8 \mathrm{mg} / \mathrm{m}^{3}$, coremaking $4.4 \mathrm{mg} / \mathrm{m}^{3}$, molding $5.6 \mathrm{mg} / \mathrm{m}^{3}$, pouring $7.5 \mathrm{mg} / \mathrm{m}^{3}$, shake-out $7.1 \mathrm{mg} / \mathrm{m}^{3}$, cleaning (fettling) $4.0 \mathrm{mg} / \mathrm{m}^{3}$, and "general foundry dust" $5.0 \mathrm{mg} / \mathrm{m}^{3}$. These values are based on the average free-silica contents of respirable dust fractions obtained in various operations during this study.

This investigation provides extensive and basic data on the magnitude and nature of current dust exposure in the Finnish foundry industry. It presents an important base line for further study.

\section{ACKNOWLEDGMENTS}

The authors wish to acknowledge the assistance provided by $\mathrm{Mr}$. Eero Aaltonen and Mr. Tauno Laukkanen during the field investigations and by $\mathrm{Mr}$. Matti Routakorpi, Mr. Ari Ovaska, Ms. Tuula Salmi, and Ms. Riitta Puttonen for their technical assistance in the laboratory studies.

\section{REFERENCES}

1. AEROSOL TECHNOLOGY COMMITTEE. Guide for respirable mass sampling. Am. ind. hyg. assoc. 31 (1970) 133-137.

2. AHLMARK, A. Silikos i. Sverige. (Studia Laboris et Salutis, Vetenskaplig skriftserie 1). Arbetsmedicinska Institutet, Stockholm 1967, pp. 224-230.

3. ANDERSSON, A., BOMAN, N., GERHARDSSON, G., ISAKSSON, G., LINDVALL, B. and MERSEBURG, M. Inom silikosprojektet använda metoder för provtagning och analys av luftburet damm. (Arbetsmedicinska Institutet T 501/70). Arbetsmedicinska Institutet, Tekniska avdelningen Stockholm 1970, pp. 15-20.
4. COENEN, W. Beurteilung verschiedener Staubmessverfahren im Hinblick auf die Ermittlung der Feinstaubkonzentration. Staub Reinhalt. Luft 30 (1970) 422-426.

5. COMITE EUROPEEN DES ASSOCIATIONS DE FONDERIES (C.E.A.F.) Kommission 2 (Hygiene und Sicherheit) Fachgruppe Staubfragen: SILIKOSE in der Giessereiindustrie, 5. Teil, Zusammenfassende Statistik für die Jahre 1959/1965, 1970 , p. 13.

6. GERHARDSSON, G., ENGMAN, L., ANDERSSON, A., ISAKSSON, G., MAGNUSSON, E. and SUNDQUIST, S. Silikosprojektets slutrapport, Del 2. Målsättning, omfattning och resultat. (Undersökningsrapport AMT 103/74-2) Arbetarskyddsstyrelsen, Stockholm 1974, pp. 165-206.

7. ISAKSSON, G. Dammsituationen vid järngjuterierna, En branschrapport. (Arbetsmedicinska Institutet $\mathrm{T}$ 603/69) Arbetsmedicinska Institutet, Tekniska avdelningen, Stockholm 1969, $195 \mathrm{p}$.

8. ISAKSSON, G. Dammsituationen vid metalgjuterier, En branschrapport. (Arbetsmedicinska Institutet T 902/69) Arbetsmedicinska Institutet, Tekniska avdelningen, Stockholm 1969. $63 \mathrm{p}$.

9. KÄRÄVÄ, R., HERNBERG, S., KOSKELA, R.-S. and LUOMA, K. Prevalence of pneumoconiosis and choronic bronchitis in foundry workers. Scand. j. work environ. $\&$ health 2 (1976): suppl. 1, 64-72.

10. KOPONEN, M., SILTANEN, E., KOKKO, A., ENGSTROM, B. and REPONEN, J. Effect of foundry size on the dust concentration of different work phases. Scand. j. work environ. \& health 2 (1976): suppl. 1, $32-36$.

11. LIPPMAN, M. "Respirable" dust sampling. Am. ind. hyg. assoc. j. 31 (1970) 138-159.

12. MEYER, R. B. Staubmessungen in der holländischen Eisengiesserei-industrie, Staub Reinhalt. Luft 33 (1973) 76-79.

13. OHMAN, H. Provtagnings- och analysförfaranden för silikosfarligt damm (AI Rapport no. 3). Arbetsmedicinska Institutet, Stockholm 1968, pp. 16-39.

14. SCHÚTZ, A. Silikosehäufigkeit und Gefährdung durch silikogenen Staub in Giessereien. Staub Reinhalt. Luft 35 (1975) 353 -357 .

15. SCHƯTZ, A. and COENEN, W. Feinstaub: Definition - Messverfahren. Staub Reinhalt. Luft 34 (1974) 323-326.

16. SILTANEN, E. and SIMEČEK, J. Staubuntersuchungen in finnischen Giessereien Staub Reinhalt. Luft 30 (1970) 1-4.

17. SIMECEK, J. and SILTANEN, E. Beitrag zur Bestimmung der Gesamt- und Feinstaubkonzentration. Staub Reinhalt. Luft 29 (1969) $460-464$.

18. SOSIAALI- JA TERVEYSMINISTERIO Työpaikan ilman epäpuhtauksien enimmäispitoisuudet (Sosiaali- ja terveysministeriön vahvistamat teknilliset turvallisuusohjeet no. 11) [Threshold limit values for contaminants in the workroom environment: Technical safety regulations no. 11]. Helsinki, 1972, p. 27. 
19. SULLY, A. H., STOCH, C. M. and SLATER, J. M. The measurement and control of dust in foundries. Br. foundryman April (1959) 193-211.

20. TOSSAVAINEN, A. and KOKKO, A. Precision and accuracy of foundry dust exposure estimates from air sampling data. Scand. j. work environ. \& health 2 (1976): suppl. 1, 13-18.
21. WAL, J. F., VAN DER. Die Messung der Feinstaubkonzentration - Einige Bemerkungen. Staub Reinhalt. Luft 35 (1975) 357 -358 .

22. WINKEL, A. Ermittlung der Verstaubung an verschiedenen Arbeitsplätzen der Eisenund Shahlindustrie. Staub 24 (1964) 497504. 